\section{Whose pain is it anyway?}

\author{
Benjamin Waller (D) 1,2
}

My 9-year-old daughter woke up the morning after a long day of gymnastics training and complained that her muscle hurts. 'I need a pill to stop the pain, NOW daddy'. Right, how do I deal with this one? Should I break out the pain education metaphors? Or give her a massage? Go for some contrast baths? I decided that the appropriate referral was a joint trip to the bakery.

Over Finnish Pulla (cardamom sweet bread), we discussed that she had delayedonset muscle soreness (DOMS), which is transient and not dangerous. During our cake-fuelled discussion, my daughter told me she had linked the use of ibuprofen for reducing a fever with helping her through the discomfort of well-earned DOMS. Rather than 'endure' the discomfort, she wanted a quick solution. If my 9-year-old daughter can make that connection, it is not difficult for others. Unfortunately, there is still excessive prophylactic use of prescribed and off-the-shelf medication in junior, amateur and elite sport, as well as the use of opioids in the management of musculoskeletal pain as shown by Australia's Ivan Lin et al (See page 79). In this Finnish issue of British Journal of Sports Medicine Sheffield's Mayur Ranchordas et al (See page 74). reviewed the use of antioxidants for preventing and reducing muscle soreness, an important topic not always effectively addressed.

Each athlete's pain experience is unique and multifactorial, but most exercise interventions for pain focus on loading the injured tissue with little thought for training the power and capacity of the processor, that is, the brain. In this BJSM edition, there are a number of insightful articles describing how to add 'neuroplastic' training, such as in Matthew Taberner's report of how to bring chaos in to the rehab programme (See page 116). The idea of adding additional cognitive task to rehabilitation is not new, but its importance is highlighted in the systematic

\footnotetext{
${ }^{1}$ Finnish Sport Physiotherapy Association (SUFT), Helsinki, Finland

${ }^{2}$ Physical Activity, Physical Education, Sport and Health (PAPESH) Research Centre, Sports Science Department, School of Social Sciences, University of Reykjavik, 101 Reykjavík, Iceland
}

Correspondence to Dr Benjamin Waller, Physical Activity, Physical Education, Sport and Health (PAPESH) Research Centre, Sports Science Department, School of Social Sciences, University of Reykjavik, 101 Reykjavík, Iceland; benw@ru.is review by Irish physiotherapist and $\mathrm{PhD}$ candidate Fionn Büttner et al (See page 94). The effect of moderate-intensity to high-intensity exercise on the brain is raising questions about the role that different intensities of training may have on the success of rehabilitation. This is a complex area of research that is growing and will probably lead some of the developments in rehabilitation in coming years (See page 110). Exercise is analgesic in many conditions, including for knee osteoarthritis. See the terrific infographic by Italian/Danish PT, PhD, Alessio Bricca et al (See page 118). However, in many other musculoskeletal conditions, the evidence is not so strong (See page 87).

\section{FINNISH SPORTS PHYSIOTHERAPY ASSOCIATION (SUFT) AND PAIN!}

This Finnish Sport Physiotherapy Association's (SUFT) edition of BJSM highlights articles relevant to the 6th SUFT Congress-5-6 June 2020: The Athlete's Pain. This will be our 6 th International Congress and first helmed by our new President Vesa Kuparinen. SUFT thanks former president Peter Halén for his contribution to SUFT local and international activities over the past years (figure 1).

At the 2020 SUFT Congress, featured as the BJSM cover for this issue (figure 2), we will be approaching questions such as how discussing and explaining pain in the biopsychosocial model fit in sport and with elite athletes. We'll also have speakers answer important questions such as: How should the physiotherapist assess the athlete and their pain? What is the management strategy? What type of exercises should we use and when, for example, isometrics versus eccentric? When do we educate and how? How much pain is enough? Should we exercise with pain? Does pain predict or slow down effective return-to-play? Passive or active treatment?

World-leading researchers and clinicians in this area have agreed to join us for a summer weekend in Helsinki. You will have the chance to engage with Dr Kieran O'Sullivan (University of Limerick, Ireland), Dr Ebonie Rio (La Trobe University, Australia), Dr Clare Ardern (Karolinska Institute, Stockholm, Sweden) and Dr Ben Smith (University Hospitals of Derby and Burton/University

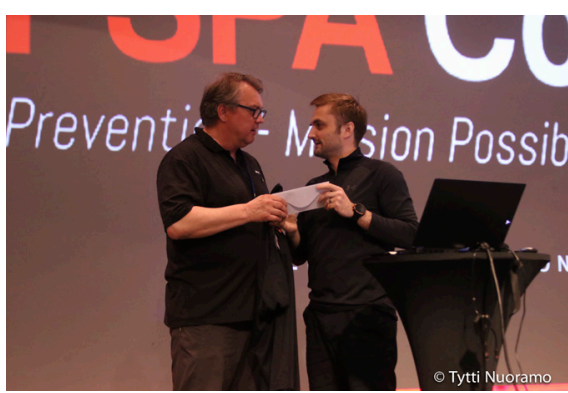

Figure 1 Presidents passing the baton: Vesa Kuparinen (right) and Peter Halén (left).

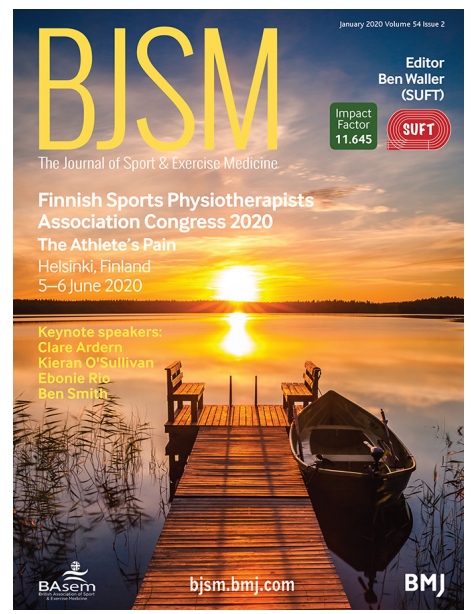

Figure 2 The always-successful Finnish Sports Physiotherapy Association Conference will take place on 5-6 June 2020.

of Nottingham, UK). See our website ( www.suftcongress.fi) for updates on the programme and special ticket offers as well as details on abstract submission.

SUFT

Twitter Benjamin Waller @BenWaller78

Contributors Content has been written fully by the author without additional contributions.

Funding The authors have not declared a specific grant for this research from any funding agency in the public, commercial or not-for-profit sectors.

Competing interests None declared.

Patient consent for publication Not required.

Provenance and peer review Commissioned; internally peer reviewed.

(c) Author(s) (or their employer(s)) 2020. No commercial re-use. See rights and permissions. Published by BMJ.

$$
\text { Check for updates }
$$

To cite Waller B. Br J Sports Med 2020;54:69.

Accepted 14 November 2019

Br J Sports Med 2020;54:69.

doi:10.1136/bjsports-2019-101782

\section{ORCID iD}

Benjamin Waller http://orcid.org/0000-0002-07380670 